\title{
INVESTIGATING THE ASYMMETRY BETWEEN ECONOMIC GROWTH AND UNEMPLOYMENT IN TURKEY: A HIDDEN COINTEGRATION APPROACH
}

\author{
DOI: 10.17261/Pressacademia.2020.1178
}

JEFA- V.7-ISS.1-2020(3)-p.22-33.

\section{Semra Boga}

Adana Aplarslan Türkeş Science and Technology University, Department of International Trade and Finance, Sarıçam, Adana, Turkey. sboga@atu.edu.tr, ORCID: 0000-0003-2799-9080

\begin{tabular}{ll}
\hline Date Received: January 29, $2020 \quad$ Date Accepted: March 2, 2020
\end{tabular}

To cite this document

Boga, S., (2020). Investigating the asymmetry between economic growth and unemployment in Turkey: a hidden cointegration approach. Journal of Economics, Finance and Accounting (JEFA), V.7(1), p.22-33.

Permemant link to this document: http://doi.org/10.17261/Pressacademia.2020.1178

Copyright: Published by PressAcademia and limited licenced re-use rights only.

\begin{abstract}
Purpose- The purpose of this study is to investigate whether there is an asymmetric relationship between economic growth and unemployment in Turkey.

Methodology- In assessing this relationship, quarterly unemployment rate and GDP data for the period between 2000-2019 were examined. Assessment of the relationship between these variables (aggregate values) was first analyzed using a Johansen cointegration test based on a system approach. While no evidence of a cointegration relationship was found, the possibility of a hidden cointegration was assessed and these variables were decomposed into positive and negative values as suggested by Granger and Yoon (2002). The asymmetric causality relationship between these variables was then evaluated using the decomposition process approach suggested by Hatemi-J and Irandoust (2012) approach.

Findings- The results of this research demonstrate an asymmetric cointegration and an asymmetric one-way causality relationship between these variables.

Conclusion- The fact that the unemployment that emerged during the contraction periods of the economy did not recover even after the economy transitioned to an expansion phase demonstrates the critical importance of the economic policies that should be implemented in times of crisis.
\end{abstract}

Keywords: Okun's Law, unemployment, economic growth, hidden cointegration, asymmetry JEL Codes: E24, O47, C23

\section{INTRODUCTION}

Achieving high and sustainable economic growth rates with low and stable unemployment rates are among the main targets of macroeconomic policies in all countries, regardless of their level of development. Unemployment is a major concern for both economists and policymakers in terms of its results. Social instability, income injustice, poverty, violence, increased crime rates, and brain drain are among the main problems triggered by unemployment. Turkey's unemployment rate of 14.2 percent is well above the Organisation for Economic Co-operation and Development (OECD) average of 5.2 percent. Youth unemployment, which has reached the level of 27.4 percent is among the most fundamental issues of the Turkish economy (OECD, 2020). Unemployment remains as a major economic and social problem in Turkey despite the significant direct and indirect incentives provided to enterprises to promote job creation.

According to the general view in the economics literature, the most important tool required to reduce unemployment is economic growth. It is a widely accepted view that the increase in Gross Domestic Product (GDP) raises employment. However, even during the periods of relatively high economic growth in Turkey no significant decline in the unemployment rate was observed. This necessitates the questioning of the relationship between economic growth and unemployment.

The first empirical relationship between unemployment and output level is based on Arthur Okun's article published in 1962. This study, which relates unemployment to losses in production, reveals that a $1 \%$ reduction in employment in the United 
States (US) economy will produce approximately $3 \%$ more output. In other words, according to the empirical findings of the study, a $1 \%$ increase in Gross National Product (GNP) will cause a $0.3 \%$ decrease in unemployment. This inverse relationship between unemployment and growth is called "Okun's Law", and the coefficient between the two variables which was found to be " 3 " for the USA is called the "Okun Coefficient". The magnitude of the coefficient is a crucial indicator in terms of the degree of interdependence of output and labor movements. Therefore, estimating the coefficient may shed light on strategic macroeconomic decisions, in particular, the determination of the optimal growth rate.

Since Okun (1962) confirmed the inverse relationship between the unemployment rate and economic growth, many studies have been conducted using different methods for various countries and country groups (Smith, 1975; Moosa, 1997; Freeman, 2001; Sögner\&Stiassny, 2002; Villaverde\&Maza, 2009). Although prior research has shown that Okun coefficient may vary depending on the time period selected, country origin of the data, and model specification (static or dynamic), the predicted negative relationship between economic growth and unemployment found in many of studies has led Okun's Law to be generally accepted among economists. However, the recovery in the US economy during 1991 and 2001, and the jobless growth in the US and European Union economies after the 2008 Global Crisis have shaken the confidence in the veracity of Okun's Law. The fact that indicators of employment have responded much more slowly to the change in output during the expansion periods of the economy has led to questioning whether the severity of changes in unemployment depends on the sign of the change in output.

Similarly, a relatively quick recovery of economic growth compared to employment following the crisis experienced in Turkey after the 1990s urged researchers to investigate the asymmetric relationship between unemployment and economic growth. The presence of this asymmetric relationship was empirically confirmed by Ceylan and Şahin (2010), Arabaci and Arabaci (2018), and more recently by Barışık et al. (2010) and Erdoğan Çoşar and Yavuz (2019). The existence of this asymmetric relationship has been tested with different methods, however, the "hidden cointegration" method has not been used in these studies conducted in Turkey. There is a limited number of studies in the literature that have investigated the asymmetry in Okun's law using the hidden cointegration method (Kangasharju et al., 2012; Koutroulis et al., 2016; Palombi, 2015).

The limited number of studies using the hidden cointegration technique in the literature and the lack of studies using this approach for Turkey constitutes the main motivation of this study. In this context, the main objective of this study is to investigate the asymmetric relationship between unemployment and economic growth in Turkey using the hidden cointegration approach. When measuring the sensitivity of the unemployment rates to GDP growth, it is important to consider the different phases of economic crises in assessing the nature of this relationship. Using a measure that includes these phases helps to provide an important criterion for policymakers when estimating the cost of unemployment and helps to guide which macroeconomic tools should be used and when they should be implemented. Harris and Silverstone (2001) also linked the importance of the asymmetric relationship between output and unemployment to four main reasons. Theoretical, empirical and political factors reasons include; (i) discriminating between theories dealing with common behavior in the labor and commodity markets, (ii) the probability of the Phillips curve to be asymmetric if the relationship representing the Okun Law is asymmetric, (iii) chosing the optimal policy mix according to the asymmetric relationship, (iv) the probability of estimation errors if the asymmetry is ignored. Ignoring an existing asymmetry will not only lead to a weak estimate but more importantly, it will lead to a misspecified model that displays incorrect inferences in hypothesis testing. The rejection of the hypothesis, which assumes a long-term relationship between output and unemployment, due to the mistake in the model may result in erroneous policy prescriptions.

In the following section, the theoretical framework of the study is introduced. In the second part, methods and findings of empirical studies investigating the relationship between the two variables are given. In the third part, the processes of the econometric analysis and the findings of the study are presented. Lastly, policy suggestions are developed by interpreting the findings.

\section{THEORETICAL FRAMEWORK: OKUN'S LAW AND THE UNEMPLOYMENT HYSTERESIS}

The negative relationship between the unemployment rate and economic growth was first introduced by Arthur Okun in the early 1960s. As his hypothesis suggests, contraction in economic growth rises unemployment in the economy. This inverse relationship is based on an empirical econometric analysis rather than a theoretical background. The absence of an economic theory that explains the relationship between the two variables enabled Okun's hypothesis to be generally accepted to measure the relationship between the two variables. There exist four different forms of Okun's Law with their advantages and disadvantages closely linked with the developed hypotheses.

In the difference version approach, analysis is started after taking the first differences of the variables.

$\left(U_{t}-U_{t-1}\right)=\alpha+\beta\left(Y_{t}-Y_{t-1}\right)+\epsilon_{t}$ 
In equation (1), $U_{t}$ indicates the unemployment rate, $Y_{t}$ represents the GDP growth, and $\epsilon_{t}$ is the error term in period $t$. In equation (1) which demonstrates how unemployment responds to the changes in economic growth, Okun's coefficient denoted by $\beta$ is expected to take a negative sign. According to this formula, an increase in growth rate will lead to a decrease in unemployment and vice versa. According to Okun's estimate for the USA, to decrease the unemployment rate by $1 \%$ a growth rate of over $3 \%$ of the potential growth rate is required. This result is based on the assumption that the unemployment equilibrium level is 4\% (Schorderet, 2001: 3). The gap version is formulated as below.

$\left(U_{t}-U^{*}\right)=\beta\left(Y_{t}-Y^{*}\right)+\epsilon_{t}$

In equation (2), $U^{*}$ indicates the natural rate of unemployment, $\mathrm{Y}^{*}$ represents the potential output and $\epsilon$ is the error term for time period t. In Okun's "gap" version, he attempts to determine what level of production will provide full employment, by focusing on "the gap" between real and potential output. Here, full employment is an economic environment where anyone who wants to work can find a job. According to Okun, high unemployment is about idle resources. In other words, the real output level is below the potential output level, and increasing production in such an environment will not create inflationary pressure. In this version, the basic assumption is that full employment is achieved when the unemployment rate is $4 \%$. The dynamic version is formulated below.

$\mathrm{U}_{\mathrm{t}}=\beta_{0}+\beta_{1} \mathrm{Y}_{\mathrm{t}}+\beta_{2} \mathrm{Y}_{\mathrm{t}-1}+\beta_{3} \mathrm{Y}_{\mathrm{t}-2}+\beta_{4} \Delta \mathrm{U}_{\mathrm{t}-1}+\beta_{5} \Delta \mathrm{U}_{\mathrm{t}-2}$

In equation (3), $\Delta \mathrm{U}_{\mathrm{t}-1}$ and $\Delta \mathrm{U}_{\mathrm{t}-2}$ show the first and the second lagged values of unemployment respectively. $\Delta \mathrm{Y}_{\mathrm{t}-1}$ and $\Delta \mathrm{Y}_{\mathrm{t}-2}$ represent the first and the second lagged values of GDP respectively.

According to Okun's observations, the current unemployment level is affected both by the current and past output levels. The production function approach of Okun's Law below shows the relationship between the past and the current output levels and the current unemployment levels.

$Y=\alpha(k+c)+\beta(\gamma n+\delta h)+\tau$

In equation (4), $\mathrm{Y}$ indicates the GDP growth in the current time period, $\mathrm{K}$ is the measure of capital input, $\mathrm{c}$ indicates input usage, $\mathrm{n}$ denotes the number of workers, $\mathrm{h}$ indicates working hours, $\alpha$ and $\beta$ represent output elasticities, $\nu$ and $\delta$ represent the contribution of workers and weekly working hours to total labor input, and $\tau$ refers to the disembodied technology factor.

According to Okun, another factor that affects the unemployment rate is the shortage of resources in various sectors. In the production process, the optimum combination of inputs in the form of labor, capital and technology should be provided to produce output. However, most work today focuses on workforce, working hours, and technological progress as determinants of economic growth. According to this version, economic growth is considered to be the function of capital, labor, and technology (Knotek, 2007).

The fact that all four equations are insufficient to analyze deeply the complex interactions between the economic growth fluctuations and unemployment changes made it necessary to investigate the relationship between the two variables by nonlinear methods. Such that it is hard to establish a regression model that connects the stationarity level of the economic growth and unemployment series. On the other hand, taking the differences of the data is not the right approach either, as it will result in ignoring the long-term relationship, which is crucial to understanding unemployment dynamics. As a result, this may lead to a wrong conclusion, claiming that the growth and unemployment series act independently of each other. According to the theory known as the "Hysteresis Paradigm", such a conclusion can be reached regarding the relationship between two variables when there is an inappropriate focus on linear models. To put it in a more technical way, although the variables in question do not appear to be cointegrated linearly, they may be in a nonlinear cointegration relationship. According to the Hysteresis Hypothesis, which rejects the assumption of linearity, economic growth series can explain unemployment levels provided that attention is paid to the asymmetric reaction of unemployment, based on the sign of economic growth. According to the hypothesis that cyclical shocks can have an effect on structural unemployment, the current period's unemployment is basically determined by the unemployment of previous years (Schorderet, 2001: 3-5).

The scenario based on the hypothesis works as follows. A recessionist shock in an economy, where the unemployment rate is $U_{0}$ and the output level is $Y_{0}$, leads to a slowdown in economic activity $\left(Y_{1}<Y_{0}\right)$ in the following period while raising the unemployment level to $U_{1}\left(U_{1}>U_{0}\right)$. When the economy enters the expansion process in the following period, output returns to the beginning level $\left(Y_{2}=U_{0}\right)$ and unemployment falls to $U_{2}$, but some of the circular unemployment that occurred due to the stagnation experienced in the past period shows that the hysteresis mechanism is functioning. In other words, the unemployment rate does not move linearly, it responds asymmetrically to the state of the economy. Unemployment reacts substantially to the situation in which the economy shows a decline, while the economy shows a slower decline in the 
recovery situation. This nonlinear feature provides important clues for explaining the unemployment series (Blanchard\&Summers, 1986; Cross, 2014).

\section{LITERATURE REVIEW}

When empirical studies examining the relationship between economic growth and unemployment are examined, it is seen that it is primarily Okun's Law that has been examined in the research. There are many studies in the literature that test symmetric, asymmetric and causality relationships between the two variables. As part of the scope of this study, this section includes studies that test the asymmetric relationship between economic growth and unemployment.

The asymmetric relationship between economic growth and unemployment was first questioned by Courtney (1991) for the USA. As a result of the analysis made with the aggregated production function approach, it was revealed that the Okun coefficient received different values during the expansion and contraction periods of the economy. Courtney (1991) attributed the root cause of this asymmetry to varying production factor substitutions, multiple factor productivity, and the changes in the distribution of sectoral growth rates at different stages of the conjuncture. His analysis used a threshold model estimator with data from the 1960-1997 period for 20 OECD countries. Virén(2001) also found evidence that the relationship between economic growth and unemployment was nonlinear. Similarly, analyzing data from the period 1978-1999 and using asymmetric cointegration and error correction models for 7 OECD countries, Harris and Silverstone (2001) concluded that unemployment rose during the economic contraction periods in the countries studied (except Canada), but the decline in unemployment did not occur in the same period of the conjuncture.

In his analysis using the Markov Regime Change model with Romanian 1991-2009 data, Caraiani (2010) showed that the negative Okun coefficient was much higher during the contraction periods of the economic cycle. Kangasharju et al. (2012) who explored the links between economic growth and unemployment in different regions of Finland by using the hidden cointegration method found that the relationship between regional output and regional unemployment is asymmetrical, and the impact of GDP expansion on unemployment is lower than that of GDP contraction.

Palombi et al. (2015) tested the relationship between regional growth and regional unemployment in the UK for the period 1983-2009 using the Granger and Yoon's (2012) hidden cointegration approach, and concluded that the positive and negative shocks to economic growth affected unemployment differently, but this asymmetric relationship was not very strong. Using the Granger and Yoon (2012) hidden cointegration approach, Koutroulis et al. (2016) examined unemployment behavior against changes in output in Greece for the period of 1990-2014 and concluded that the relationship between the two variables is asymmetric.

Barışık et al. (2010) investigated the asymmetric relationship between economic growth and unemployment in Turkish economy for 1988-2008 period using the Markov Regime Change method, and found that the unemployment rate falls during periods of contraction if the actual output exceeds the potential output. On the other hand, they did not find a significant relationship between the unemployment rate and the output during the expansion periods. Ceylan and Şahin (2010) examined the asymmetry between economic growth and unemployment using the TAR and M-TAR cointegration analysis for the 1950-2007 period. Their findings approved the presence of asymmetric Okun's law in Turkey.

Applying the Markov Regime Change Model to the annual data for the 1969-2014 period, Akay et al. (2016) tested the interactions between economic growth and unemployment and found that Okun's relationship was asymmetric in the relevant period. According to these findings, growth during the contraction period decreases unemployment more than the growth during the expansion period.

To analyze the linkages between the cyclical components of unemployment and output in Turkey, Arabaci and Arabaci (2018) implemented a flexible nonlinear inference approach. The findings of the study revealed that the expansion and contraction conditions in the economy have an asymmetric impact on unemployment. The research has also identified a certain level of the output gap at which the "jobless growth" occurs. According to the findings, in the middle phases of the economy's expansion state, the cyclical component of production tends to increase, while the cyclical components of unemployment do not show a downward trend. In a recent study conducted by Erdoğan Çoşar and Yavuz (2019), the asymmetric relationship between the GDP and employment was estimated by applying the Markov switching model to the 1989-2018 quarterly series. In the study where the Okun's law was tested, employment and unemployment rates were found to be more susceptible to negative shocks in economic growth.

\section{ECONOMETRIC ANALYSIS}

It is not always the right approach to model relationships between time series using ordinary econometric models. When the relationship between the non-stationary time series is estimated with estimators based on the assumption of stationarity, 
such as Ordinary Least Squares (OLS), there is a possibility that the relationships that do not actually exist can be found statistically significant. Such relationships are referred to as spurious regression in the literature and lead to unreliable $t$ and F statistics (Gujarati, 2015: 320). For this reason, the estimations made with non-stationary variables are not reliable and the series should be made stationary with various operations and then the analysis may be used. However, it is not always seen as a correct approach to make the non-stationary variables stationary at the first stage and then to establish a model. Because a possible long-term synchronous relationship between the variables disappears when the series are stationary with difference taking operations. Thus, all traces of the cointegration relationship, which can be defined as a special case in which combinations of two or more non-stationary variables exhibit a stationary $(I(0))$ structure, are lost and a regression coefficient expressing the short term is obtained. However, the cointegration relationship expresses a very special relationship structure in econometrics. Therefore, it is necessary to check whether there exists a cointegration between non-stationary variables at the level, and if not, the series should be made stationary to avoid the problem of spurious regression. However, the cointegration relationship between variables may not always appear in the first stage.

\subsection{Hidden Cointegration Approach}

The hidden cointegration approach developed by Granger and Yoon (2002) criticizes the traditional cointegration detection methods based on the logic that the cointegration relationship occurs when economic variables react synchronously to shocks (Mert\&Çağlar, 2019: 299).

$$
x_{t}=x_{t-1}+\varepsilon_{t}=x_{0}+\sum_{i=1}^{t} \varepsilon_{i}
$$

and

$$
y_{t}=y_{t-1}+\epsilon_{t}=y_{0}+\sum_{i=1}^{t} \epsilon_{i}
$$

In both equations shown above $\mathrm{t}=1,2, \ldots, x_{0}$ and $y_{0}$ represent the initial values, $\varepsilon_{i}$ and $\epsilon_{i}$ indicate the zero-mean white noise series. Both variables $\left(x_{t}\right.$ and $\left.y_{t}\right)$ given in equations (5) and (6) show the aggregate state of series. The decomposition process to be performed at this stage is based on the separation of the error terms according to negative and positive shocks. The error decomposition process is in the forms of:

$\varepsilon_{i}^{-}=\min \left(\varepsilon_{i}, d\right)$ and $\varepsilon_{i}^{+}=\max \left(\varepsilon_{i}, d\right) ; \epsilon_{i}^{-}=\min \left(\epsilon_{i}, d\right)$ and $\epsilon_{i}^{+}=\max \left(\epsilon_{i}, d\right)$ with the variables shown as $\varepsilon_{i}=\varepsilon_{i}^{-}+\varepsilon_{i}^{+}+d$ and $\epsilon_{i}=\epsilon_{i}^{-}+\epsilon_{i}^{+}+d$. It is also assumed that $\varepsilon_{i}^{+}, \varepsilon_{i}^{-}, \epsilon_{i}^{+}$and $\epsilon_{i}^{-}$follow the I(1) process (Granger ve Yoon, 2002: 6). In the equations, " $d$ " indicates the threshold value and is usually assumed to be equal to zero. When these values are replaced in equation(5):

$x_{t}=x_{t-1}+\varepsilon_{t}=x_{0}+\sum_{i=1}^{t} \varepsilon_{i}^{-}+\sum_{i=1}^{t} \varepsilon_{i}^{+} \quad$ and $y_{t}=y_{t-1}+\epsilon_{t}=y_{0}+\sum_{i=1}^{t} \epsilon_{i}^{-}+\sum_{i=1}^{t} \epsilon_{i}^{+}$equations are obtained respectively. Assuming $x_{0}$ and $y_{0}$ are the intercepts in the next step:

$x_{t}=x_{0}+x_{t}^{-}+x_{t}^{+}$and $y_{t}=y_{0}+y_{t}^{-}+y_{t}^{+}$are rewritten. The shocks obtained here constitute the first stage of hidden cointegration analysis. Also, Granger\&Yoon (2002) investigated the cointegration relationship for four different states of two variables such as $X$ and $Y$ (Granger\&Yoon, 2002: 9). Granger and Yoon (2002) hidden cointegration results are obtained if the Engle and Granger (1987) test is applied to the decomposed values of the series. On the other hand, if the Johansen cointegration analysis based on the system approach is applied to the decomposed values, Hatemi-J and Irandoust (2012) hidden cointegration results will be obtained.

\subsection{Johansen Cointegration Analysis - Vector Error Correction Model (VECM)}

In the cointegration analysis approach put forward by Engle and Granger (1987), a single cointegration relationship is obtained. However, in their study, Johansen (1988), Johansen and Juselius (1990), and Johansen (1996) defined more than one cointegration or equilibrium relationship analysis in series by examining possible equation systems between the series. All series in the equation system where Johansen cointegration analysis will be applied must demonstrate the I(1) process. If the time series vector for cointegration relationship testing is defined as $Y_{t}=\left(X_{1 t}, X_{2 t}, \ldots, X_{m t}\right)$, the relationship between the variables can be written as: 


$$
Y_{t}=A_{1} Y_{t-1}+A_{2} Y_{t-2}+\cdots+A_{p} Y_{t-p}+\varepsilon_{t}
$$

The error correction model (VECM) is obtained from this equation as follows:

$$
\Delta Y_{t}=\Gamma_{1} \Delta Y_{t-1}+\Gamma_{2} \Delta Y_{t-2}+\cdots+\Gamma_{p-1} \Delta Y_{t-p+1}+\Pi Y_{t-1}+\varepsilon_{t}
$$

In this equation, the long-term parameter is a parameter with two components: $\Pi=a \beta^{\prime}$. The parameter $B^{\prime}$ refers to the longterm coefficient, while the parameter $a$ indicates the rate of adjustment of the long-term parameter. Equation (9) is obtained if equation (8) is rewritten by taking into consideration the two parameters as shown below.

$$
\Delta Y_{t}=\Gamma_{1} \Delta Y_{t-1}+\Gamma_{2} \Delta Y_{t-2}+\cdots+\Gamma_{p-1} \Delta Y_{t-p+1}+a\left(\beta^{\prime} Y_{t-1}\right)+\varepsilon_{t}
$$

In equation (9), $6^{\prime} Y_{t-1}$ denotes the vector error correction term (VECT). $6^{\prime} Y_{t-1}$ contains (m-1) number of vectors. $Y_{t}$, which follows the I(1) process as mentioned earlier, will be following $\left(\Delta Y_{t}\right) I(0)$ process when its first difference is taken. Therefore, in order for $\varepsilon_{t}$ to be $\mathrm{I}(0)$ process, it is necessary either for $\pi \mathrm{Y}_{\mathrm{t}-1}$ or $\boldsymbol{6}^{\prime} Y_{t-1}$ to be $\mathrm{I}(0)$ process. The following conditions can be mentioned with $\operatorname{Rank}(n)=\mathrm{r}$ :

- If the rank of the matrix $n$ is equal to the number of $m$, all the series in the $Y_{t}$ vector will be the $\mathrm{I}(0)$ process, and in such a case, the cointegration relationship cannot be mentioned.

- In the case of $r=0$, there is no linear relationship between the series in $Y_{t}$ vector, so the matrix of mxm size and a zero matrix will appear. In such a case, it will be concluded that there is no cointegration relationship between the variables.

- In the case of $r \leq(m-1)$, it is understood that there is a cointegration relationship between the variables.

Thus, the presence of the cointegration relationship between the series actually depends on determining the rank(r) of the matrix $n$. Johansen (1988) and Johansen (1996) used the trace statistics and maximum eigenvalues of the matrix to determine the " $r$ ". For this purpose, five different models of the VECM model are determined as shown in the equation number (9). These models are created by adding and removing the short and long-term deterministic components. Equation (9) transforms into the following form when all deterministic components are added:

$$
\Delta Y_{t}=\Gamma_{1} \Delta Y_{t-1}+\Gamma_{2} \Delta Y_{t-2}+\cdots+\Gamma_{p-1} \Delta Y_{t-p+1}+a\left(\begin{array}{c}
\beta \\
\mu_{1} \\
\delta_{1}
\end{array}\right)\left(\begin{array}{lll}
Y_{t-1} & 1 & t
\end{array}\right)+\mu_{2}+\delta_{2} t+\varepsilon_{t}
$$

Here, the intercept $\mu_{1}$ (i.e. cointegration term (CE)) and trend $\delta_{1}$ can be found in the long-term model. Similarly, in the shortterm model (i.e. VAR), the intercept $\mu_{2}$ or trend $\delta_{2}$ may also be included. Five different VECMs result from possible combinations, however, this study uses the model 4 . Model 4 has an intercept as well as a trend in its long-term form. In the short-term, while there is an intercept, there is no trend $\left(\delta_{2}=0\right)$ and it can be shown as follows:

$$
\Delta Y_{t}=\Gamma_{1} \Delta Y_{t-1}+\Gamma_{2} \Delta Y_{t-2}+\cdots+\Gamma_{p-1} \Delta Y_{t-p+1}+a\left(\begin{array}{c}
\beta \\
\mu_{1} \\
\delta_{1}
\end{array}\right)\left(\begin{array}{lll}
Y_{t-1} & 1 & t
\end{array}\right)+\mu_{2}+\varepsilon_{t}
$$




\section{3. Unit Root Tests}

\subsubsection{Augmented Dickey-Fuller (ADF) Unit Root Test}

The Augmented Dickey-Fuller (ADF) unit root test which is often preferred when performing unit root analysis in time series, is considered as a similar version of the Dickey-Fuller (DF) unit root test that takes advantage of the AR(1) process. However, if there is a higher degree of correlation in the time series examined, $\varepsilon_{t}$ (error term sequence) loses its white noise sequence feature. In the ADF test, to overcome this problem, instead of the AR(1) process the lagged difference term " $p$ " is included in the equation by making use of the AR(p) process (Dickey and Fuller, 1979: 427). Thus, ADF equations without intercept and non-trend (12), with intercept (13), and with intercept and trend (14) are shown as follows:

$$
\begin{aligned}
& \Delta y_{t}=\delta y_{t-1}+\sum_{i=1}^{p} \beta_{i} \Delta y_{t-i}+\varepsilon_{i} \\
& \Delta y_{t}=\mu+\delta y_{t-1}+\sum_{i=1}^{p} \beta_{i} \Delta y_{t-i}+\varepsilon_{i} \\
& \Delta y_{t}=\mu+\beta t+\delta y_{t-1}+\sum_{i=1}^{p} \beta_{i} \Delta y_{t-i}+\varepsilon_{i}
\end{aligned}
$$

In equations (12), (13), and (14) the term $\mu$ represents the intercept, $p$ is the number of lags, $\varepsilon_{t}$ is the error term, and t refers to the trend in equation (14). The null hypothesis developed for all three ADF equations is $b_{i}=0$ (there is a unit root in the series)(Gujarati, 2015: 326).

\subsubsection{Phillips-Perron (PP) Unit Root Test}

Dickey-Fuller and Augmented Dickey-Fuller tests assume that the error terms are independent of each other and have a fixed variance (Enders, 2004: 190). However, it has been observed that most of the time series have heterogeneous distributions and weakly dependent error terms. Thus, Phillips and Perron (1988) proposed a unit root test taking into account the possibility of autocorrelation between the error terms. There are also nonparametric corrections in this test. The equation for the test is as follows:

$$
\Delta y_{t}=a y_{t-1}+x_{t}^{\prime} \delta+\varepsilon_{t}
$$

In this equation, while a corresponds to $\rho-1$, " $x_{t}$ " specifies the deterministic components (intercept or intercept\&trend) and " $\varepsilon_{t}$ " denotes a series of error terms. The null and the alternative hypotheses belong to the PP tests are " $H_{0}: \alpha=0$ ve $H_{1}: \alpha<$ $0 "$ and the null hypothesis indicates that the series contain a unit root (Çağlayan\&Saçaklı, 2006: 124).

\section{DATA, EMPIRICAL FINDINGS AND DISCUSSION}

In the analysis, Unemployment is the dependent variable and the GDP is the independent variable. Quarterly data belongs 2000-2019 period in Turkey obtained from the TCMB-Evds database. Econometric analyses were carried out through the Eviews 10+ program. The model examined during econometric analysis is shown in closed form as below:

$$
\text { Unemployment }=f(G D P)
$$

The open form of the regression is written as below:

$$
\text { lnUnemployment }_{t}=\alpha_{0}+\beta_{1} \ln G D P_{t}+\varepsilon_{t}
$$


Table 1 shows the intercept and intercept and trend ADF and PP unit root test outcomes for the level values of both macroeconomic series, including the decomposed values. The results indicate that the series contain a unit root. At this stage, it is concluded that the series are not stationary at $\mathrm{I}(0)$.

Tablo 1: ADF and PP Unit Root Tests- Level

\section{ADF Unit Root Test}

PP Unit Root Test

\begin{tabular}{|c|c|c|c|c|}
\hline Variables & $\tau$-Stat. (Cons.) & $\tau$-Stat. (Cons. and Trend) & Adj. t Stat. (Cons.) & Adj. t Stat. (Cons. and Trend) \\
\hline \multirow[t]{2}{*}{ Unemployment } & -2.580238 & -2.481713 & -2.411531 & -3.026116 \\
\hline & $(0.1017)$ & $(0.3361)$ & $(0.1420)$ & $(0.1320)$ \\
\hline \multirow[t]{2}{*}{ GDP } & -0.420839 & -2.332048 & -0.439103 & -2.601287 \\
\hline & $(0.8995)$ & $(0.4118)$ & $(0.8962)$ & $(0.2810)$ \\
\hline \multirow[t]{2}{*}{ Unemployment $^{+}$} & -2.312765 & -2.583497 & -2.409237 & -2.601287 \\
\hline & $(0.1708)$ & $(0.2890)$ & $(0.8962)$ & $(0.2810)$ \\
\hline \multirow[t]{2}{*}{ Unemployment } & -1.732302 & -1.610764 & -2.411531 & -2.288076 \\
\hline & $(0.4109)$ & (0.7791) & $(0.1420)$ & $(0.4350)$ \\
\hline \multirow[t]{2}{*}{$\mathrm{GDP}^{+}$} & -0.975363 & -1.883564 & -1.163551 & -2.048500 \\
\hline & $(0.7582)$ & $(0.6533)$ & $(0.6862)$ & $(0.5655)$ \\
\hline \multirow[t]{2}{*}{ GDP- } & -2.056553 & -2.940636 & -1.847359 & -2.505300 \\
\hline & $(0.2627)$ & $(0.1563)$ & $(0.3552)$ & (0.3249) \\
\hline
\end{tabular}

Table 2 shows the ADF and PP unit root test results of the first differentiated aggregate and decomposed series. It was observed that the unit root in the series disappeared with the difference taking operation. Thus, the degree of integration of all series was recorded as " 1 " and it was seen that the first condition for the hidden cointegration test was met at this stage.

\section{Table 2: ADF and PP Unit Root Tests- First Difference}

ADF Unit Root Test

\begin{tabular}{|c|c|c|c|c|}
\hline Variables & 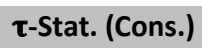 & $\tau$-Stat. (Cons. and Trend) & Adj. t Stat.(Cons.) & Adj. t Stat. (Cons. and Trend) \\
\hline \multirow[t]{2}{*}{$\Delta$ Unemployment } & -3.568189 & -4.068313 & -9.153008 & -9.077794 \\
\hline & $(0.0088)^{*}$ & $(0.0106)^{* *}$ & $(0.0000)^{*}$ & $(0.0000)^{*}$ \\
\hline \multirow[t]{2}{*}{$\Delta \mathrm{GDP}$} & -7.704549 & -7.653486 & -7.699622 & -7.647428 \\
\hline & $(0.0000)^{*}$ & $(0.0000)^{*}$ & $(0.0000)^{*}$ & $(0.0000)^{*}$ \\
\hline \multirow[t]{2}{*}{$\Delta$ Unemployment $^{+}$} & -6.146420 & -6.668912 & -6.147220 & -6.639244 \\
\hline & $(0.0000)^{*}$ & $(0.0000)^{*}$ & $(0.0000)^{*}$ & $(0.0000)^{*}$ \\
\hline \multirow[t]{2}{*}{$\Delta$ Unemployment $^{-}$} & -5.143556 & -5.562345 & -9.474572 & -10.58295 \\
\hline & $(0.0000)^{*}$ & $(0.0000)^{*}$ & $(0.0000)^{*}$ & $(0.0001)^{*}$ \\
\hline \multirow[t]{2}{*}{$\Delta \mathrm{GDP}^{+}$} & -8.192927 & -8.203439 & -8.212171 & -8.348808 \\
\hline & $(0.0000)^{*}$ & $(0.0000)^{*}$ & $(0.0000)^{*}$ & $(0.0000)^{*}$ \\
\hline \multirow[t]{2}{*}{$\triangle \mathrm{GDP}^{-}$} & -6.559928 & -6.688310 & -6.744142 & -6.888102 \\
\hline & $(0.0000)^{*}$ & $(0.0000)^{*}$ & $(0.0000)^{*}$ & $(0.0000)^{*}$ \\
\hline
\end{tabular}

The upper part of Table 3 shows the results of the Johansen Cointegration test which investigated the cointegration relationship between the aggregate states of the series. In the hidden cointegration analysis, since the Hatemi-J and Irandoust (2012) approach was preferred, the VECM $(4)^{1}$ model was found to be the best model through Model 4 , where the theory was also mentioned in equation (11). This model has been determined as the most appropriate model since it is the smallest AIC value model within the desired properties of the error correction coefficient and without varying variance and autocorrelation problems. In the Johansen cointegration test based on this model, it was observed that the null hypothesis, which stated that there was no cointegration relation, could not be rejected, thus, no long-term relationship between these variables was established. From this point, a possible hidden cointegration relationship was investigated. As proposed by Granger ve Yoon

${ }^{1} \mathrm{VECM}(4)$ is the model without autocorrelation and heteroscedasticity problems and has the lowest AIC and SIC values among other models. 
(2002) variables were decomposed into negative and positive values and after this stage, a synchronous relationship between the series was analyzed with a cointegration testing method as suggested by Hatemi-J ve Irandoust (2012). In the literature, this approach is called as Granger ve Yoon (2002) hidden cointegration approach when the Engle-Granger (1987) cointegration test is applied to the decomposed series and called as Hatemi-J ve Irandoust (2012) hidden cointegration approach when Johansen cointegration test is applied (Mert\&Çağlar, 2019: 300).

Tablo 3: Cointegration Test Results

\begin{tabular}{llllll}
\hline Johansen Cointegration Test & & & & \\
\hline Dependent Variable & Independent Variable & Null Hypotesis & Eigenvalue Stat. & Trace Stat. & p-Value \\
\cline { 9 - 9 } & GDP & None & 0.181479 & 20.88669 & 0.1843 \\
(VECM 4) & & At Most 1 & 0.085919 & 6.468227 & 0.4033
\end{tabular}

Serial Correlation LM Test- LRE Stat. 1.413419

(0.8419)

White Heteroskedasticity Test- $\chi^{2}$ Stat. 70.39521

(0.3328)

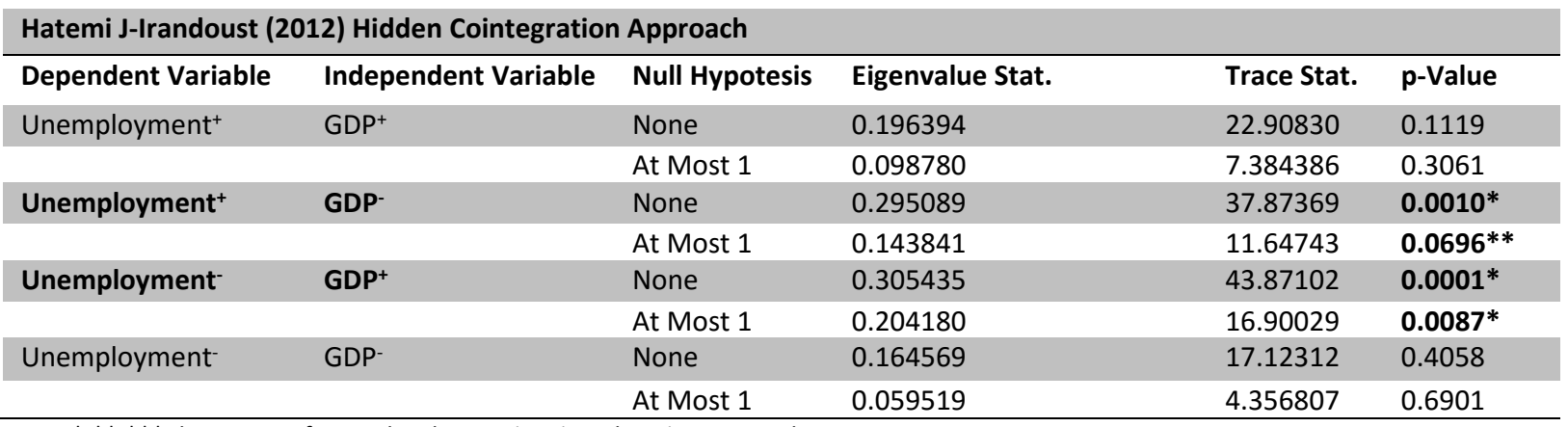

Note: $* * *, * * *$ denote significance levels at $1 \%, 5 \%$, and $10 \%$ respectively.

The Johansen cointegration test was applied to the decomposed series and based on the econometric model (unemployment is the dependent and GDP is the independent variable), four possible outcomes (Unemployment ${ }^{+}-\mathrm{GDP}^{+}$; Unemployment ${ }^{+}$GDP-; Unemployment--GDP; Unemployment- GDP+) arose. According to the results of the hidden cointegration approach, for two different situations, the null hypothesis that there is no cointegration relationship between the series is rejected. A cointegration relationship between the series Unemployment ${ }^{+}$- GDP- and Unemployment - GDP $^{+}$was determined. Thus, as stated by Granger and Yoon (2002), the variables did not react to shocks in the same direction. Figure 2 and Figure 4 show the plots of the variables with the cointegration relationship (Unemployment ${ }^{+}$, GDP-; Unemployment', GDP+). The other figures, show the situations in which the cointegration relationship is sought, but evidence of this relationship is not found.

Figure 1: Unemployment ${ }^{+}-G D P^{+}$

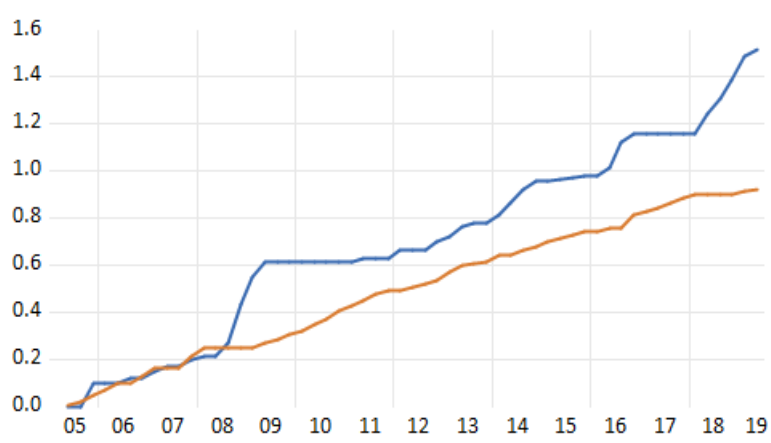

Figure 2: Unemployment ${ }^{+}-$GDP-

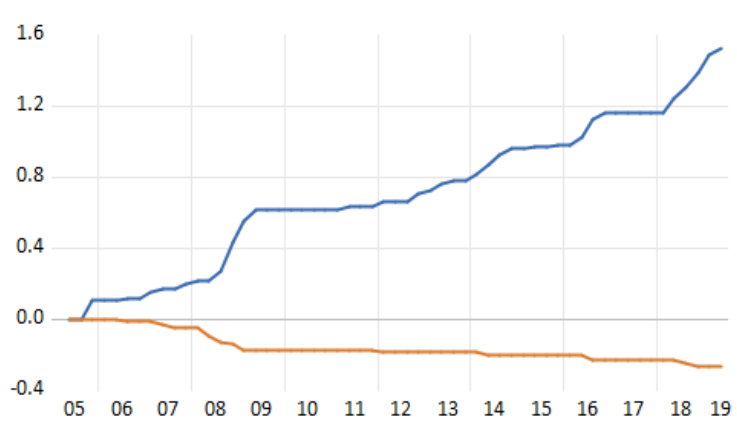


Figure 3: Unemployment'-GDP-

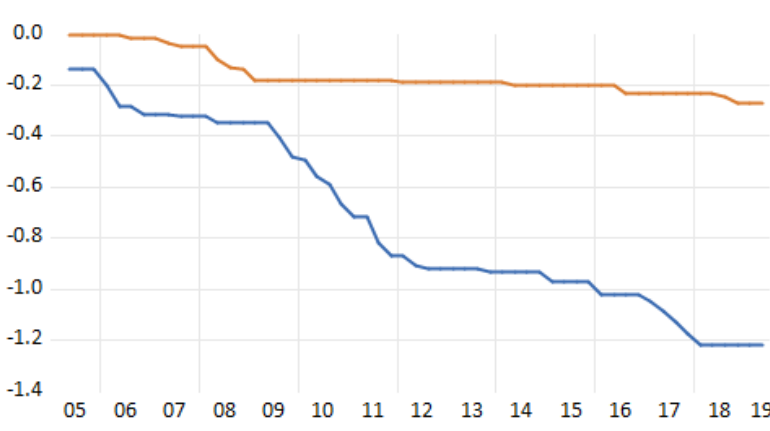

Figure 4: Unemployment- -GDP+

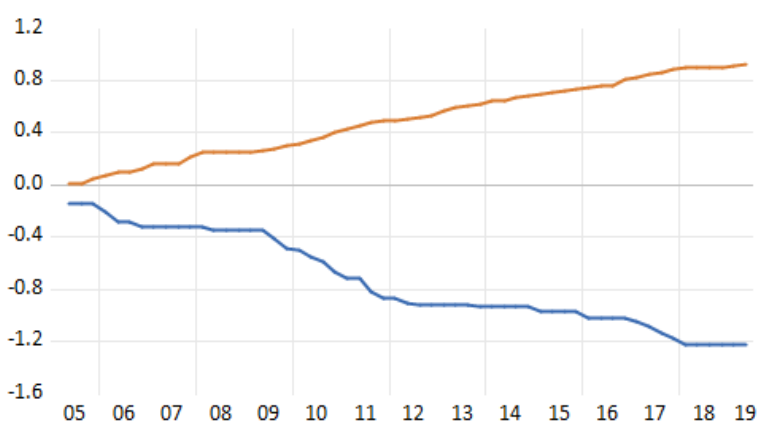

Table 4 shows the estimation of the hidden cointegration model. It is observed that a $1 \%$ positive shock (also called a positive development) in the GDP in the long term reduces unemployment by $0.78 \%$, and a $1 \%$ negative shock in the GDP increases unemployment by $1.21 \%$.

The cointegration models (long term) predicted for the variables that have a cointegration relationship between them are written as follows:

Unemployment $t^{+}=2.845-1.213 G D P_{t}^{-}+0.0169 \times$ Trend

Unemployment ${ }_{t}^{-}=1.281-0.786 G D P_{t}^{+}-0.0057 x$ Trend

Tablo 4: Hidden Cointegration Model / Long-Run Estimation

\begin{tabular}{|l|l|l|}
\hline & Model 1 & Model 2 \\
\hline & $\begin{array}{l}\text { Dependent Variable } \\
\text { Unemployment }\end{array}$ & $\begin{array}{l}\text { Dependent Variable } \\
\text { Unemployment }\end{array}$ \\
\hline GDP- $^{-}$ & -1.213307 & -0.785761 \\
\hline GDP $^{+}$ & {$[-13.51874]$} & {$[-10.43368]$} \\
\hline t-stat. & $(0.0897)^{* * *}$ & $(0.0753)^{* * *}$ \\
\hline$p$-Value & 0.030572 & -0.005612 \\
\hline Trend & {$[-5.04592]$} & {$[-0.90546]$} \\
\hline t-stat. & $(0.00606)^{*}$ & $(0.00620)^{*}$ \\
\hline$p$-Value & 2.849095 & 1.280986 \\
\hline Constant & VECT-1 & VECT-2 \\
\hline & -0.112529 & \\
\hline Coefficient(ECT-1) & & -0.079652 \\
\hline Coefficient(ECT-2) & {$[-5.41004]$} & {$[-4.42512]$} \\
\hline t-stat. & $(0.0208)^{* *}$ & $(0.0180)^{* *}$ \\
\hline$p$-Value & \\
\hline
\end{tabular}

Note: $*, * *, * *$ denote significance levels at $1 \%, 5 \%$, and $10 \%$ respectively.

\section{CONCLUSION}

Economic growth and employment are among the main macroeconomic targets of all countries, regardless of their level of development. Okun's Law assumes a negative and linear relationship between output and unemployment changes. However, just like other macroeconomic variables, unemployment can react differently to economic growth at different stages of the 
economic cycle. In other words, interactions between these two macroeconomic indicators are more complex than it seems. The objective of this study is to investigate the asymmetric cointegration between economic growth and unemployment relationship for Turkey. In this study which used the quarterly data for the period 2000-2019, the hidden cointegration and asymmetric causality relationship between these variables were tested. The results of the analysis showed that unemployment increased during periods of economic contraction, but employment did not recover in the same period when the economic recovery began, that is, when GDP turned to positive. Thus, it was confirmed that Okun's Law shows asymmetric behavior in Turkey. Having not found a linear relationship between the variables offers important clues for understanding the overall dynamics of the labor market in Turkey and requires the consideration of this asymmetrical relationship in implementing the macroeconomic policies.

The fact that the unemployment that emerged during the contraction periods of the economy did not recover even after transitioning to the expansion phase of the economy once again demonstrated the importance of the economic policies that should be implemented in times of crisis. The most traditional policy approach for this process, which is explained by the "hysteresis" mechanism in the literature and is characterized as "jobless growth", is monetary and fiscal policies aimed at stimulating economic activity, especially in economies working below its potential. However, it is not always possible to find a solution to the unemployment problem through standard policy practices. The most important consequence of long-term economic recessions is that unemployment becomes a structural problem over time, which requires a transformation in the policies to be implemented. In this context, there is a need for practices that will enable both workers and employers to take the right steps in the labor market, which acts differently during the period of contraction and expansion of the conjuncture. An important strategy that can be implemented is to ensure that the workers who leave the sectors that shrank in times of crisis are directed to the sectors with growth potential. Providing different skills to workers with trainings will be an important factor that can increase employment. Employment incentives given to employers until the crisis periods are overcome, especially in cases of temporary fluctuations, can be an important tool for avoiding the situation with less social and economic damage in terms of unemployment.

\section{REFERENCES}

Akay, H. K, Aklan, N. A., \& Çınar, M. (2016). Türkiye Ekonomisinde Ekonomik Büyüme ve İşsizlik. Yönetim ve Ekonomi Araştırmaları Dergisi, 14(1), 209-226. DOI: 10.11611/JMER775

Arabaci, Ö. ,\& Arabaci, R. Y. (2018). A Flexible Nonlinear Inference to Okun's Law for Turkish Economy in the Last Decade. Panoeconomicus, 65(5), 569-586. DOI: 10.2298/PAN130913026A

Barışık, S., Çevik, E. İ., \& Çevik, N. K. (2010). Türkiye'de Okun Yasası, Asimetri İlişkisi ve İstihdam Yaratmayan Büyüme: Markov-Switching Yaklaşımı. Maliye Dergisi, 159, 88-102.

Blanchard, O. J., \& Summers, L. H. (1986). Hysteresis and The European Unemployment Problem. National Bureau of Economic Research Working Paper No. 1950. DOI: 10.3386/w1950

Caraiani, P. (2010). Bayesian Linear Estimation of Okun Coefficient for Romania: Sensitivity to Prior Distributions. The Romanian Economic Journal, 13(38), 53-65. DOI: 10.1556/AOecon.60.2010.1.5

Ceylan, S., \& Şahin, B. Y. (2010). İşsizlik ve Ekonomik Büyüme illişkisinde Asimetri. Doğuş Üniversitesi Dergisi, 11(2), 157-165. DOI: 10.31671/dogus.2019.159

Courtney, H.G. (1991). The Beveridge Curve and Okun's Law: A Re-Examination of Fundamental Relationships in the United States. Ph.D. Thesis, Massachusetts Institute of Technology.

Cross, R. (2014). Unemployment: Natural Rate Epicycles or Hysteresis? European Journal of Economics and Economic Policies: Intervention, 11 (2), 136-148. DOI: 104337//EJEEP.2014.02.01

Çağlayan, E., \& Saçaklı, İ. (2006). Satın Alma Gücü Paritesinin Geçerliliğinin Sıfır Frekansta Spektrum Tahmincisine Dayanan Birim Kök Testleri ile Incelenmesi. Iktisadi ve Idari Bilimler Dergisi, 20(1), 122-137

Dickey, D.A., \& Fuller, W. A. (1979). Distribution of the Estimators for Autoregressive Time Series With a Unit Root. Journal of the American Statistical Association. 74(366), 427-431. DOI: 10.2307/2286348.

Enders, W. (2004). Applied Econometric Time Series, Second Edition, United States of America: John Wiley \& Sons,.

Engle, R., \& Granger C. (1987). Cointegration and Error Correction Representation: Estimation and Testing. Econometrica. 55, 251-276. DOI: $10.2307 / 1913236$ 
Erdoğan Çoşar, E., \& Yavuz, A. A. (2019). Is There Asymmetry between GDP and Labor Market Variables in Turkey under Okun's Law? Central Bank of the Republic of Turkey Working Paper No. 19/27.

Freeman, D. G. (2001). Panel Tests of Okun's Law for Ten Industrial Countries. Economic Inquiry, 39(4), 511-523. DOI: 10.1093/ei/39.3.511

Granger, C.W., \& Yoon, G. (2002). Hidden Cointegration. University of California, University of California Economics Working Paper No. 200202. DOI: $10.2139 /$ ssrn. 313831

Gujarati, D. (2015). Econometrics by Example (2nd ed.). London, United Kingdom: Macmillan International Higher Education.

Harris, R., \& Silverstone, B. (2001). Testing for Asymmetry in Okun's Law: Cross-country Comparison. Economics Bulletin, 5, 1-13.

Hatemi-J, A., \& Irandoust, M. (2012). Asymmetric Interaction Between Government Spending and Terms of Trade Volatility: New Evidence from Hidden Cointegration Technique. Journal of Economic Studies. 39(3), 368-378.

Johansen, S. (1988). Statistical Analysis of Cointegration Vectors. Journal of Economic Dynamics and Control. 12(2-3), 231-254.

Johansen, S. \& Juselius, K. (1990). Maximum Likelihood Estimation and Inference on Cointegration with Application to the Demand for Money. Oxford Bulletin of Economics and Statistics, 52(2), 169-210.

Johansen, S. (1996). Likelihood-based Inference in Cointegrated Vector Auto-regressive Models. 2nd ed. Oxford: Oxford University Press.

Kangasharju, A., Tavera, C., \& Nijkamp, P. (2012). Regional Growth and Unemployment: The Validity of Okun's Law for the Finnish Regions. Spatial Economic Analysis, 7(3), 381-395. DOI: 10.1080/17421772.2012.694141

Knotek, E. S. (2007). How Useful is Okun's Law?. Economic Review-Federal Reserve Bank of Kansas City, 92(4), 73-103.

Koutroulis, A., Panagopoulos, Y., \& Tsouma, E. (2016). Asymmetry in the Response of Unemployment to Output Changes in Greece: Evidence from Hidden Co-integration. The Journal of Economic Asymmetries, 13, 81-88. DOI: 10.1016/j.jeca.2016.03.003

Mert, M., \& Çağlar, A.E. (2019). Eviews ve Gauss Uygulamalı Zaman Serileri Analizi. Ankara: Detay Yayıncılık.

Moosa, I. A. (1997). A Cross-Country Comparison of Okun's Coefficient. Journal of Comparative Economics, 24(3), 335-356. DOI: 10.1006/jcec.1997.1433

OECD (2020), Unemployment rate (indicator). DOI: 10.1787/997c8750-en (Accessed on 12 January 2020)

Okun, A. M. (1962). Potential GNP: Its Measurement and Significance. Proceedings of the Business and Economics Statistics Section, American Statistical Association, 98-103.

Palombi, S., Perman, R., \& Tavera, C. (2015). Regional Growth and Unemployment in the Medium Run: Asymmetric Cointegrated Okun's Law for UK Regions. Applied Economics, 47(57), 6228-6238. DOI: 10.1080/00036846.2015.1068922

Phillips, P. C. B., \& Perron, P. (1988). Testing for a Unit Root in Time Series Regression. Biometrika, 75(2), 335-346. DOI: 10.1093/biomet/75.2.335

Schorderet, Y. (2001). Revisiting Okun's Law: An Hysteretic Perspective. University of California, San Diego.

Smith, G. (1975). Okun's Law Revisited. Quarterly Review of Economics and Business,15, 37-53.

Sögner, L., \& Stiassny, A. (2002). An Analysis on the Structural Stability of Okun's Law - A Cross-country Study. Applied Economics, 14, 17751787. DOI: $10.1080 / 00036840210124180$

Villaverde, J., \& Maza, A. (2009). The Robustness of Okun's Law in Spain, 1980-2004: Regional Evidence. Journal of Policy Modeling, 31(2), 289-297. DOI: 10.1016/j.jpolmod.2008.09.003

Virén, M. (2001). The Okun Curve is Non-Linear. Economics Letters, 70, 253-57. DOI: 10.1016/S0165-1765(00)00370-0 